\title{
Instagram Photography of Havana: Nostalgia, Digital Imperialism and the Tourist Gaze
}

\section{REBECCA OGDEN}

University of Kent

\section{Abstract}

This article proposes to add Instagram photography to a historical visual mapping of Havana during a period of renewed visibility. Further enabled by the features of Instagram's format to 'age' photos and highlight specific textures and colours, these images draw on and contribute to a nostalgic vision of an exotic, underdeveloped Havana. Instagram photography emerges as an important touristic mode of imagining and experiencing the city. Yet despite the aesthetic overdetermination of these images, their captions and hashtags often stymie any suggestion of political meaning. Nevertheless, the networked image, organized and anchored by metadata such as the geotag and hashtag, further cements the signifier 'Havana' to the photographic image, and confirms the city as worthy of the gaze. Lastly, the paper reflects on the broader profile of those creating and circulating Instagram images of the city, arguing that a relative lack of access to digital technologies in Cuba has resulted in a strongly asymmetric gaze from the outside in.

\section{$\underline{\text { Resumen }}$}

Este artículo propone agregar la fotografía de Instagram a una cartografía visual histórica de La Habana durante un período de renovada visibilidad. Gracias a las características del formato de Instagram para 'envejecer' las fotografías y resaltar texturas y colores específicos, estos retratos contribuyen a la imagen nostálgica, exótica y subdesarrollada de la ciudad. La fotografía de Instagram surge como un importante modo turístico de imaginar y experimentar la ciudad. Sin embargo, a pesar de la sobredeterminación estética de estas imágenes, la sugerencia de algún significado político a menudo se ve obstaculizada por sus títulos y hashtags. Sin embargo, el mosaico de imágenes 'en la red', que se organiza y se ancla por metadatos como el geotag y el hashtag, enlaza el significante 'La Habana' con la imagen fotográfica y confirma que la ciudad es digno objeto de la mirada turística. Por último, el artículo reflexiona sobre el perfil de quienes crean y circulan imágenes de la ciudad en Instagram, sosteniendo que la falta relativa de acceso a las tecnologías digitales en Cuba ha dado lugar a una percepción fuertemente asimétrica desde el exterior.

The last four years have been significant in terms of Cuba's visibility and exposure to global flows. Visits made by US celebrities have garnered intense media interest. ${ }^{1}$ The tourism sector, which saw a sudden, accelerated expansion in the 1990s, amidst austerity and crisis, recorded 4.73 million arrivals in 2018 ('Cuba espera' 2019). Both foreign tourists and 'armchair tourists' online had greater access than ever before to photographs of Cuba: in 2016, images of Barack Obama's visit and of the high profile Chanel fashion show in Havana's Paseo del Prado circulated online. In 2015, Anne Leibowitz photographed the singer Rihanna in haute couture beside dilapidated buildings, cracked paintwork and vintage cars for a Vanity Fair feature titled 'Our Woman in Havana'. The combination of these tropes constitutes an enduring aesthetic that has become increasingly synonymous with Havana.

In 2019, tourist photography on Instagram contributed in a significant way to this visual allure and, in turn, the global fascination with and flow of tourists to Cuba. This article undertakes to add Instagram to a longer history of visually 'mapping' Cuba since the 1990s (Dopico 2002) and the Caribbean more generally since the nineteenth century. Expanding tourist gaze theory (Urry 1990) to encompass approaches to social media and the networked image (Rubinstein and Sluis 2008), it considers the representational power of Instagram photography. First, the article examines the framing of specific sites and scenes. Further enabled by Instagram's specific format, tourist images on the platform draw on and contribute to a nostalgic aesthetic of an exoticized, underdeveloped Havana, further cementing the city's position as a deteriorating, and thus desirable, destination. An analysis of the comments and captions that accompany the image sample

\footnotetext{
${ }^{1}$ I would like to thank Núria Triana-Toribio, Peter Buse, Par Kumaraswami and the reviewers for their feedback on draft versions of this paper. I am also grateful to the Association of Hispanists of Great Britain and Ireland for the Dorothy Sherman Severin Fellowship which supported this research and to Niamh Thornton for her mentorship during the fellowship.
} 
reveals that despite the aesthetic overdetermination of these framings, the potential for broader political reflections is often stymied. Second, the paper reflects on the significance of Instagram photography's networkedness. How can we conceptualize tourist images of Havana shared on social media as a further dimension to the 'photographic bounty' associated with the city and its inhabitants since the 1990s? (Dopico 2002: 451). While photographic representations of Havana have been explored before (Quiroga 2005; Kent 2019), tourists' images - online or offline - have not been analysed in any serious way. What difference does it make in terms of aesthetic, temporal and networked potentialities that these photos are created, shared and viewed online, corralled by metadata into specific sequences? Due to the uneven access to digital technologies and internet connectivity in Cuba, the broader profile of creators in this digital gaze further skews the asymmetry of the city's visual representation, constituting a gaze from the outside in. The article suggests that Instagram hosts a form of 'digital imperialism'.

\section{Tourism, photography and Cuba}

Images are the 'lifeblood' of the global tourism industry (Edwards 1996: 216). Photography in particular has become so central to tourism that it seems to have become 'a strategy for accumulating photographs' (Sontag 1977: 9). This ocularcentrism of tourism - the highly visual nature of knowing peoples, places, and pasts - is conceptualized by John Urry as the 'tourist gaze' (1990). The tourist gaze refers to the largely unconscious but intensely visual force by which peoples, places and pasts are classified and consumed through tourism (Hollinshead 1999: 10) and the industries that help to construct and develop that gaze by drawing our attention to particular objects of apparent value (Urry 1990: 1). The capturing tourist gaze thus associates the sign to its signifier; the world of tourism is 'crowded' with these associative relationships (MacCannell 1999: 117). Long before travel occurs, a notion of place has been well established in the mind's eye (Urry 1990: 3).

This visual order has particular relevance to the Caribbean. Nineteenth-century visual representations of the Caribbean photographs, postcards, photography books, illustrated guides, stereo-views and lanterns - confirmed the region as a tropical and picturesque tourism destination (Thompson 2006). Visions of these unknown worlds were made familiar to European audiences through travel publications, reflecting an imperial 'obsession' to see and know colonized peripheries (Pratt 2008: 4). In particular, a firm interrelationship developed between the Caribbean, tourism and photography. From the nineteenth to the twentieth centuries, "not only did tourism promoters use photography to reconstitute an image of [Caribbean] islands, but they marketed their landscapes and inhabitants as picturesque, more specifically, as photographs' (Thompson 2006: 8). In constituting and confirming certain places as 'kodakable' (Sheller 2003: 66) tourism continues to condition Caribbean islands and their inhabitants within a broader system of imperial power.

Nineteenth and early twentieth-century images of Cuba in magazines and travel guides were laden with sensuous promise (Levi and Heller 2002: 15; Schwartz 1999). Havana in particular served as 'a projection screen for Western fantasies' (Dopico 2002: 452). By the mid twentieth century, US consumers and audiences had developed what Gustavo Pérez Firmat dubs the 'Havana habit', an appetite for the simultaneously exotic and familiar, which framed Havana as an alluring, sensual atmosphere and a cinematic shorthand for Latin American otherness (2010: 24). Yet after 1959 photography displayed, within and outside Cuba, the new allegiances to nation and Revolution (Quiroga 2005: 81). Havana's visual power shifted in this revolutionary reconfiguration of the nation (Bobes 2011: 17). Instead, images of the interior, of 'peasants, or fields of sugarcane, flourishing lands, emerging peoples, schools in the countryside... showed the vigorous torso of the nation' (Fornet 2007, cited in Bobes 2011: 28). Cultural and industrial investments outside Havana in the following decades of the Revolution mirrored this re-evaluation of the city's representational dominance - at home, if not abroad.

However, the fall of the Soviet Bloc in 1989 resulted in a sudden and catastrophic collapse of the Cuban economy and a decade of intense austerity, prompting a fresh recalibration of Havana's economic, political and representational significance. During this so-called Special Period, Havana returned as the locus of economic potential and, thus, internal migration; in the early 1990s, urban overcrowding saw 51.4 per cent of buildings in the city centre transformed (and eventually weakened and damaged) by the use of barbacoas, informal room divisions creating an extra mezzanine level 
(Real and Scarpaci 2011). Transport services ground to a halt, compromised food supplies led to widespread malnutrition, and power cuts lasted for hours, sometimes days. The dormant tourism sector was rapidly developed through foreign investment, but brought with it complex social contradictions such as the devalorization of state jobs, a two-tier economy, and prostitution. This period of economic, social and ideological crisis occurred alongside a renewed foreign interest in all things Cuban (Behar 2002; Dopico 2002: 359). This revitalized currency created new markets for travelogues and literature (Whitfield 2008). Havana's visual appeal, in particular, was exploited by new branding narratives, magazine journalism (Berg 2004), film (Fehimović 2018), music documentaries (Kent 2017) and glossy photography books (Dopico 2002: 464). Havana returned as a source of potent symbolic value both domestically and internationally. From the 1990s onwards, visual representations of Havana had taken on a 'distinct aesthetic quality', in which images of ruin and decay set against vintage music were 'signifiers of authenticity and resilience', as Ariana Hernández-Reguant describes (2009: 13). The key subjects of this 'alluring visual syntax' were crumbling architecture and 'the apparently candid beauty of Cuban faces' (Dopico 2002: 465), resonant with ideological anxieties concerning the frailty of revolutionary socialism and the resilience of the impoverished population. Such tropes are linked to what Esther Whitfield (2008) has defined as a 'postSoviet exotic', a recurring aesthetic in cultural representations that announced a lost utopia: a world not as it was, but 'as some hoped it might be' (2008: 22).

Images circulated by photographers, journalists, tour operators and tourists have continued to fuel Havana's currency as a desirable (but fading) destination, and have in turn generated hard currency through the tourism sector. Indeed, tourism the primary economic survival mechanism for both the state and many individuals since the 1990s - has relied on this visual fetishization. The imaginary of a crumbling Havana has also produced a return flow in the form of cameratoting tourists hoping to 'see Cuba before it changes'. During this same period, an explosion in the use of camera phones and development of social media platforms have led to an immense 'avalanche' of online images (Rubinstein and Sluis 2008). As tourists' photos have become more shareable with a wider audience online, they have increasingly contributed to the tourist gaze. Social media is therefore a rich source from which to consider the 'hermeneutic circle' of the tourist gaze the seeming exigency to track down sites that appear in other tourists' photos, and to take more photos (Jenkins 2003; Urry 1990: 140). Iconic places become further celebrated through this circle of representation.

Instagram: frame, filter, publish, like

Despite Instagram's staggering growth since its 2010 creation to an estimated 1 billion global users in 2019 there has been little scholarly focus on the app's significance to tourism. Exceptions include studies on selfie-taking as touristic identityconstruction (Dinhopl and Gretzel 2016), and photo-sharing as a communicative connection with home (Larsen, Urry and Axhausen 2007). Instagram is a social media platform with a simple format: it is a photo editing and sharing tool. The application allows users to add captions, searchable hashtags, filters, frames, annotations and other effects to still images and videos. Filters chosen by the user may alter photographs through high saturation, black and white or sepia effects, low resolution, or yellowed fuzziness. Published images then appear in the algorithm-curated 'feeds' of other users. The nostalgic aesthetic of Instagram's early design is significant. Some filters and other effects (such as the Polaroid frame) that still form part of the app are designed to make digital photographs look as though they were taken on an older analogue camera, rather than the expensive smartphones required to use the app in the first place. Contemporary revivals of retro technology and pseudo-vintage aesthetics may be linked to a sense of authenticity attributed to the 'offline' and the analogue in a hypermediated and hyperconnected world, even while their popularity and even existence may be predicated on the digital dissemination of data.

The circulation and consumption of travel photos on the app provide a form of 'virtual sensory tourism' (Thornton 2010). Although photos are posted by individuals, hashtags allow for photos within a particular theme to be grouped into a virtual 'gallery': search 'Havana', 'LaHabana' or 'Cuba' and images accordingly geo-tagged or hashtagged appear, posted by users all over the world. In short, the coalescing of these images online contributes towards the global visibility and visual consumption of the city and its inhabitants. Recognizing and knowing distant places, despite never visiting, 'does not just challenge our senses of home and away, but in fact rewrites them' (Mostafanezhad and Norum 2018: 131). 
In addition, identities may be constructed and performed on Instagram (Tiidenberg and Baym 2017). Researchers have emphasized the link between online usergenerated content and new social practice (MacDowall and de Souza 2017; Leaver and Highfield 2018), that is, the impact of social media in moulding cultural and social behaviours in 'real life'. Instagram's central conceit is to display the photographer's world, through their eyes: it thus allows the performance and projection of an individual's taste, cultural capital and mobility.

Big data approaches tend to dominate social media research, despite the associated risks of enabling a simplistic or 'apophenic' analytic tendency when 'enormous quantities of data... offer connections that radiate in all directions' (Boyd and Crawford 2012: 668). Instead, a mixed-methods approach that both draws out big data through quantitative tools and applies qualitative methods for analysis may be especially meaningful in exploiting and interrogating social media data (Highfield and Leaver 2015). Using big data approaches gives a 'birds-eye' view according to its metadata - the volume of images posted during different periods, for instance, or by geography. Quantitative measures can identify a sample according to the researcher's intended requirements, as well as further sort the sample by metadata. It is also useful to engage with quantitative tools to gather a sufficiently broad sample in order to avoid, for example, a selection of images according to algorithms within the app, which may instead be determined by the researcher's profile. Yet visual analysis is also necessary when considering the meanings and implications of those images. Rather than to simply calculate, for example, the number of images which feature a specific location (such as Capitoleo), the intention behind this research was to interrogate how specific subjects and sites were framed, filtered, captioned, and engaged with.

Researchers of Instagram have tended to use the app's application programming interface (API) to pull or 'scrape' a data set using a metadata query (Leaver and Highfield 2018; Honig and MacDowall 2017). Metadata includes information recorded by the digital device when the photo was taken (date, time, location, technology of photographic device) and data that is produced when the image is engaged with online networks (through practices such as geo- and hash-tagging, comments, likes and views). This approach has allowed researchers to access a selective sample of images according to the hashtags added to captions, by when and where they were posted, by what type of profile (number of followers).

However, since data privacy has become a serious legal controversy for Instagram's parent company Facebook, accessing metadata in this way is no longer straightforward. As a result, a necessarily creative approach was used for this project. First, I used the website Webstagram to identify frequently used hashtags associated with Havana, including Spanish, French and Russian spellings (La Habana, Наvane, Гавана) in order to find photos shared by visitors from Cuba's main tourist markets, and by locals. Some hashtags generated through Webstagram were not relevant, relating to product names or song references, and were disregarded. The selected hashtags are:

\#havana

\#habana

\#lahabana

\#habanavieja

\#havanavieja

\#Гаван

\#havanacuba

\#oldhavana

\#havane

\#lahavane

\#lahavana

\#havanastyle

I also used the geotagging function: although 'live' posting in Cuba is hampered by restricted internet connectivity, users often tag the location when posting at home. Second, following Leaver and Highfield (2018), I 'followed' these hashtags and geotags through my personal account for a period of three months between December 2018 and February 2019 so as to have a general overview of the kinds of images shared and to refine or eliminate any hashtags that resulted in irrelevant 
images. This method grouped tagged images in my feed as they were posted, but were subject to Instagram's algorithms. However, given the impossibility of 'scraping' a large data set through the API, I considered this a worthwhile means to gaining an initial overview. Third, I signed up to a corporate social media monitoring tool called Brand24, and selected a 48-hour period in February 2019 to track the chosen hashtags, aiming to replicate Leaver and Highfield's (2018) method, which extends from a broader overview to a more micro-level analysis. This generated a sample of 2,497 photos. I used the tool's access to metadata to refine those results in order of popularity (likes and/or profile follows over 1,000), prioritizing those images that were visible to a greater number of Instagram account holders. Since my focus was on the representation of the city, any photos that appeared to advertise products, that related to Camila Cabello's song 'Havana', or were otherwise irrelevant were disregarded. Rather than images posted by corporate or industry accounts which have otherwise been the focus of tourism gaze theory (Hollinshead 1999), I focused on personal accounts (tourist and amateur) which mirrored a travelogue, narrative style. The sample was limited to those posted on public accounts for practical reasons and in the interests of privacy.

A resulting sample of 440 images was confirmed for closer analysis. The size of this final sample corresponds to other analyses of the representation of a specific place or phenomenon on Instagram (Webb et al. 2019). Because the corporate monitoring tool did not allow me to 'save' the images, I instead used the links it provided to the original post on Instagram, created a screenshot to capture the image including caption and comments, and saved these screenshots in NVivo. Using NVivo I began to code the images according to common elements or sites, filters and visual effects, captions and comments. The project primarily focussed on visual representation, but comments and captions were taken into account to qualify the context and intention of a chosen image, recognizing that there can be ambiguity relating to the user's intentions, and others might have added hashtags in their comments that did not relate to the original image. Taking the volume of comments into account can also allow one to quantify positive, negative or neutral engagement with the image; a review of the sample indicated that the majority of comments are posted soon after the image is published. The findings of key recurring themes are described below.

\section{Havana on Instagram}

Many images had a nostalgic aesthetic. Havana's recognizable vintage cars (almendrones) appeared in 190 of the 440 sampled images. In many of these images, filters had been used to dramatically intensify colours: cars in electric blue and Barbie-pink are often the cartoon-ish centre of the image, bright clothing stands out, and buildings in primary colours clash with one another (Figure 1). It is only the incongruously intense blue of the sky that makes the lurid hyper-intensity of the chosen filter apparent.

However, a larger proportion of the photos in the sample used a faded colour palette. In addition, in focussing on the urban everyday and decaying buildings, many perpetuate the post-Soviet 'visual syntax' identified in Dopico's study of photography books (2002). In particular, dilapidated buildings appeared prominently in a third of the sampled images. Tourists continue to be drawn to photograph grand buildings that have fallen into disrepair because of extreme austerity, long-term scarcity of state-distributed building materials, overcrowding, informal and inexpert repairs, and the inevitable erosion of paintwork by sea air. Instagram's grey and sepia washes heighten the dystopian flavour of these cityscapes. In one example image (Figure 2), the contrast has been heightened to make dark areas darker and light areas lighter, which gives the image more of a gritty, sharp edge. In contrast to Figure 1, the small section of sky appears white and the image appears 'busier', as each dark edge is further contrasted against its white backdrop. Cracks and shadows are drawn out by the app's editing tools, emphasizing dilapidation and neglect. Mirroring many other images in the sample, buildings take up the majority of the frame in Figure 2; they are the city's primary subject. Residents who do appear in the photograph are dwarfed by buildings and tend to disappear amongst the additional visual 'noise' of zig-zagging wires and mismatched balcony styles and paint colours. Lines of laundry that stretch across balconies represent the many inhabitants within, and speak to the residential overcrowding in Old and Central Havana. Domestic routines of cleanliness, evident in the drying sheets, are contrasted with the clear dilapidation and disrepair of urban buildings. 
Few images included Havana's modern architecture, social housing and slick hotels, although a number featured the expensively restored historic centre. Despite Havana's varied urban space and architecture, there is an insistence on valuing and aestheticizing architectural ruins (Kent 2011: 208-09), bearing out a broader 'ruin lust' (Dillon 2014) or 'ruin porn' (Lyons 2018) in visual culture. Indeed, in the Instagram caption in the image shown in Figure 2, the prized 'charm' of the damaged buildings depicted makes Havana worthy of 'bucketlist' status. Together, caption and image confirm Havana's timewarp appeal as they simultaneously express pleasure in signs of decay and a desire to perpetuate them.

While Instagram accounts run by the Cuban Ministerio de Turismo (MINTUR) and state agency Havanatur feature celebrated and iconic tourist sites, this sample suggested that tourist users are often more likely to photograph the urban everyday: schoolchildren, people waiting on street corners, payphones, graffiti and drying laundry. Quotidian tasks and the act of getting by, adjusting to and surviving scarcity and poverty through creative means - referred to in Cuba by the terms luchando or resolviendo - are elevated by their inclusion in the frame (Figure 3). In Figure 3 the subjects are occupied in the task of repairing a mains pipe, turned away from the photographer. In Figure 4, two Havana residents cross the road, one carrying a refuse sack, backs turned to the camera. It is hard to imagine a more banal or everyday scene. Yet hashtags such as 'people', 'street photography' and 'everydaycuba' extend the value of such mundane images to prized representations of authenticity. Unlike typical tourist photos, which might capture the tourist in front of a landmark, these images bear greater resemblance to reportage-style photography. They visually recall mid-twentieth and early twenty-first century photographic essays of Havana, evoking Walker Evans' People Waiting at Trolley Stop, Havana (1933) and Claudio Edinger's living room scenes in Old Havana (1998, cited in Dopico 2002: 473). Such photographic choices appear to confirm the continued validity of Dean MacCannell's argument that tourists are fascinated by the 'real lives' of others - somehow more real than their own (1973).

Figure 2. Beautiful Havana...

Source: Instagram.com/eat.shop.travel

Figure 3: Working on the Cuban streets

Source: Instagram.com/auroraluna

Figure 4: Havana street life

Source: Instagram.com/josvdp87

Several photos within the sample reveal attempts to capture the interior of private, often domestic, spaces (Figure 5). Tourists' quest to gaze on intimate settings is satisfied through staged 'back spaces' (MacCannell 1999: 95); tourists to Cuba may be especially conscious of the threat of inauthentic, censored experiences (Ogden 2019: 4). The sample revealed attempts to photograph the insides of homes from the outside, or capture residents at windows or on front steps. While Cubans 'before and beyond the Revolution are accustomed to being the subjects of a foreign gaze', as Dopico argues (2002: 465), the camera intrudes, turning the subject into object (Barthes 1981: 23). The immediacy of taking tourist photographs provokes complex ethical considerations and negotiations, and prompts strategies to overcome discomfort or to mitigate the intrusion of the lens (Scarles 2013). As photographs are increasingly taken with the specific intention that they be shared with (often unknown) others online, the ethics of tourist photography are complicated further. The 'constellation of moral intentions' (Scarles 2013: 901) that lie behind the dominant tourist gaze are multiplied in complex ways when that gaze is expanded to social media sharing. In many images gathered as part of this study, subjects' faces are turned from the camera. Figure 5 shows a grand doorway leading to a courtyard, revealing, as in a 
Dutch interior painting, evidence of life inside, and a resident. The eye is immediately drawn to the intimate interior framed by the orange door at the centre of the photograph. Two young boys sit on the step outside, one watching the street while the other covers his face. Yet the Instagram caption in the image - 'Jugando al cucú' - suggests that to turn away from the tourist gaze is little more than a game.

In contrast, some images feature close-up portraits of anonymous Havana residents staring directly into the lens. Such images circumvent any associative shame that might normally obstruct or complicate the gaze in real life. Portraits offer a kind of candidness, an open regard which is rarely possible through spoken words due to the necessity of mutual trust between interlocutors, or confianza, in the context of market-driven social relations and society's communicative 'cloudiness' since the Special Period (often referred to as 'doble moral'). Portraits of Havana residents are counterpointed with portraits of fashion or travel bloggers. The connection between Havana and fashion has become increasingly established in recent years, as major brands have shot adverts in the capital and exploited Havana's exotic 'essence' as part of their product marketing. ${ }^{2}$ Instagram photography has also drawn on and confirmed the notion that Havana is fashionable. Just as with other fashion photography, such as Rihanna's Vanity Fair shoot of November $2015^{3}$, this mise en scène directly contrasts sartorial luxury with urban decay or faded colonial opulence (referred to as 'majestically dilapidated' and 'insta-worthy' in the image's caption). Such a contrast further emphasizes the glamour and femininity of the subject, a suggestion that her beauty jars with the decaying surroundings (Gasiorowski 2019: 75).

Figure 5: "Jugando al cucú"

Source: Instagram.com/auroraluna

Figure 6: If you only visit one restaurant in Havana, make it La Guarida

Source: Instagram.com/eat.shop.travel

Images such as Figure 6 implicate not just the representation of place in the tourist gaze, but the performance of the tourist self. The tourist selfie reflects the changing meaning and potential of tourism - especially when sought as experiences of Otherness - to allow for personal self-development and growth (Picard and Di Giovine 2014: 2). In turn, Instagramming tourism underlines how the performance of self often eclipses the representation of destination (Mostafanezhad and Norum 2018). The photographer-subject places herself front and centre in order to authenticate her experience and daring self-identity; she is framed on each side by pillars, while the chandelier draws the eye back to her silhouette. Her stride, evident in the movement of her skirt and her straightened shoulders, suggests purpose and present self-assuredness, and implies an impromptu nature to the photo-taking. Yet the caption ('check out the before/ after edits') instead evinces specific intention. Indeed, images of tourists and bloggers striding away from the camera are now common on Instagram. Images like these tend not to include other subjects; the captions are often suggestive of the (usually female) subject's cultural capital and intrepidness: she will often use the following hashtags: \#sheisnotlost, \#dametraveler, \#wearetravelgirls, \#girlsvsglobe, \#darlingescapes, \#femmetravel, \#girlsthatwander. Including herself in the frame, her images announce 'I was there' (Sontag 1977: 9), or indeed, when posted live to social networks, 'I am there right now' (Dinhopl and Gretzel 2016: 127). It further carries traces of imperial intention, confirming the Instagrammersubject as the protagonist of their own travel narrative (Pratt 2008: 73). The caption cites a tourist hotspot, La Guarida restaurant, made famous by the film Fresa y chocolate. ${ }^{4}$ Despite its popularity, the subject appears alone, distancing

\footnotetext{
${ }^{2}$ A 'Havana Blues' scented body oil, sold by retailer And Other Stories, is marketed as a product that 'leaves the skin feeling satin smooth and divinely scented with tobacco leaves withering among beloved jasmine and ripe lemon'. Revlon's Havana Collection, advertised via a viral video featuring Caucasian models in Afro wigs, 'invites us to vacation in an exotic setting, where the spontaneous takes on strength, volume and movement' (see https://www.youtube.com/watch? v=1J_92xnp5JA. Accessed 10 December 2020).

${ }^{3}$ See www.vanityfair.com/hollywood/2015/10/rihanna-cover-cuba-annie-leibovitz. Accessed 3 November 2020.

${ }^{4}$ Fresa y chocolate/ Strawberry and Chocolate (1993, dir. Tomás Gutiérrez Alea and Juan Carlos Tabío).
} 
herself literally and figuratively from the much-derided mass tourist. Similarly, selfies taken in front of Havana landmarks perform an imperial 'I-am-there-ness', staking claim to these places and their currency.

A consideration of the captions that accompany images indicated limited attempt to make political or ideological commentary. Candid portraits of habaneros are often signifiers of authenticity and resilience, and of the Revolution and nation in tragic decline (Dopico 2002: 474). Similarly, images of Havana's ruins seem to urge an allegorical reading, as Birkenmaier and Whitfield have observed (2011: 4). Yet photography that fetishizes the grubby urban everyday may risk being emptied of politics, as Quiroga reflects, if they are simply apprehended 'as a metaphor for something' (2005: 82). The Instagram captions infrequently alluded to socio-economic and political realities, but did not go further. For example, one Instagram image of a child looking up to the camera from behind the iron bars of a fence was captioned 'Conditional freedom', while another of a man staring back at the lens from inside a window of his home was captioned 'Boxed in'. Such captions allude to the personal restrictions placed on Cuban citizens by government policies and the US embargo but stop short of developing these observations beyond mere suggestiveness. It may be argued, in line with HernándezReguant's observations about photography of Havana since the Special Period (2009), that the prevalence of unposed portraits of Cubans at work or engaged in domestic and menial tasks (even resolviendo) suggests a certain solidarity with and admiration of Cubans' dignified resilience in the face of economic and political pressures.

The dominance of such framings in the tourist gaze of Havana is worthy of comment, particularly as other touristic destinations are not experienced and photographed in the same way. In also privileging images of dilapidated buildings and interiors, often but not always alongside such suggestive captions, these tourist images imply a subtext of regret concerning the deterioration of the city, nation and revolutionary project. In repeating these tropes but rarely expanding on their significance through captions or hashtags, the images carry within them but fail to explicitly articulate the broader political implications humming in the background. Nor is the more general disparity of capital and mobility between local and tourist photographer, a symptom of Cuba's accelerated exposure to global markets, fully represented. Captions for figures 1, 2 and 6 cited in this article reflected much of the larger sample in referring to the tourist's personal experience of Havana beyond the photograph. As the broader meanings of these visual shorthands of authenticity and resilience - crumbling buildings, interiors, and habaneros engaged in their everyday lives - are ultimately deflected by their captions, the viewer is encouraged to appreciate and consume the photograph on essentially aesthetic terms. A review of the comments left by others also reveals a tendency to appreciate the aesthetic of the image and the value of the depicted tourist experience rather than any further social, economic or political reality.

Tourism is undoubtedly one of the main factors responsible for the changes that are most lamented by tourists: tourism booms have led to business interest from big corporations such as airbnb and facilitated the sudden unequal flows of goods and capital apparently corrupting Cuba's egalitarian social fabric. If, following Sontag, by fixing moments in time, 'all photographs testify to time's relentless melt' (1977: 15), then visions of Havana on Instagram can be seen as a metaphor for the nostalgia that is experienced through but essentially provoked by tourism. The touristic impulse to capture the present ('before it changes') by photographing symbols of the past and inferring the uncertainty of an increasingly globalized future is worthy of remark. Havana functions as a living museum that allows tourists to travel back to a series of accumulated pasts (pre-1959 and pre-1989) and take photographs that evoke a rare nostalgia. In framing sites of decay and 1950s cars, rather than any of the newer hotels or cars which also make up the urban skyline, Instagram images participate in a broader discursive and visual fixing of Havana (symbolizing revolutionary Cuba) as frozen in time. Conversely, challenges of the present and recent past appear in the deterioration of the physical landscape (Quiroga 2005: 82): crumbling buildings and other markers of underdevelopment make visible the damage wrought by the last three decades of austerity. Adding vintage filters and effects to images intensifies this aesthetic, but may also make digital photographs look retro and analogue, and as a result further de-historicizes the image. Therefore, while on the one hand there are enough tropes of an established imaginary of Havana to root the photographs in place (portraits of Che in faded paintwork, 1950s cars, and the Malécon), on the other hand, it is a decidedly dehistoricized aesthetic with multiple and elusive temporal indicators. 
The networked image

Photos shared by tourists online further establish Cuba as a trophy destination characterized by aestheticized decay and nostalgia, just as they take their lead from the enduring visual regime conceptualized by Kent (2019), Dopico (2002), and Quiroga (2005). However, the essential difference between the analogue images they consider and Instagram photography is that the networked image is connected to a vast online library of images through the use of hashtags, captions and metadata, which may 'anchor' the meaning intended by the photographer, making them searchable and thus visible to others amongst an immense slew of images on the internet (Rubinstein and Sluis 2013). Metadata 'renders the image a calculable surface' (2013: 153), readable and categorizable by computers, determining how they circulate and are consequently encountered by human audiences. Hashtags regiment these images together in an extensive series of meaning: when one enters 'Havana' or 'LaHabana' into Instagram, a ream of images appears. ${ }^{5}$ To understand the represented city through the networked image therefore means a recognition of the strong connection between the content of the photograph and its format or form. The networked image, anchored and organized by metadata such as the geotag and the hashtag, grafts the signified of the photograph further to the signifier 'Havana'. Dopico's observation (2002: 451) of the tendency to conflate Havana with the photographic image since the emergence of Special Period tourism - and further, to see the capital as visual shorthand for Cuba, the nation, and the apparent collapse of the socialist project - is intensified by the increasing number of online images. The volume of images of Havana posted and circulated on Instagram, and the hashtags and geotags which activate their utility and visibility online, reinforce the synonymity of city and image. As the data presented in this paper suggests, the specific vision of the city continues to be characterized by repetitive tropes.

More importantly, for Instagram photographers, scenes are imagined as shareable images before they are encountered, indicating a continuum between the tourist gaze and the construction and marketing of certain sites as valuable and worthy of the gaze. Indeed, to call a destination 'instagrammable' and 'instaworthy', as some travel journalists have done with reference to Havana (Cabrera 2017) is to acknowledge that the place is imagined before it is seen, principally prized as a photograph. Captions and comments revealed that Instagram photos posted by others were key in motivating the photographer's desire to travel to Cuba, to take photographs (and to post them on Instagram): one commented, 'I've seen so many pictures posted by bloggers and I thought that I wanted to see that through my own eyes!'. The memory that the image signifies is seen in the mind's eye before it has been has been experienced or documented by the cameraphone. The use of hashtags such as \#wanderlust, \#starttheadventure and \#passionpassport also reflect a desire to connect with others through the tourist gaze and make images visible to (virtual) tourist audiences. As such, Instagram is more than simply another platform to display images of Havana, but instead facilitates the visiting, photographing, sharing and consuming of the city in new ways. As a driving motivation for travel, the social media photograph as a scopic mode is less about recording the touristic experience in the present as it is about anticipating the experience via the networked gaze.

Furthermore, because the majority of images that circulate on the platform and online more generally - up until very recently - are posted by tourists and seen by foreign audiences, Instagram photography's semiotic organization (adhering the identity of signifying hashtag to image) is primarily directed by the tourist gaze. Despite the interrelatedness of flows of capital, people and (digital) information in contemporary tourism, tourists and Cubans have substantially different access to online platforms such as Instagram. The development of technology on the island has been incomplete and staggered; access to smartphones and the internet remains the privilege of a minority of Cubans. The Cuban norm of offline consumption of digital content, exemplified in the circulation of the paquete semanal through advanced distribution

\footnotetext{
${ }^{5}$ Clearly, for untagged images the sheer volume of images of the internet push these representations to the bottom of the endless scrolling gallery and eventually out of sight. To conceptualize such images instead as a 'data stream', according to Nadav Hochman (2014), forces a revision of our understanding of time: while the database is a static record of information that is accessed on request, time-stamped visual information in data streams emphasizes linearity and affirms the temporal as its foremost 'organizational and communicational factor' (Hochman 2014: 3).
} 
networks of memory drive sharing, speaks to a primarily pre-networked experience of the internet in Cuban society. Statistics from 2018 indicate that just over 12 per cent of the population have personal computers (ONEI 2019: 7); far fewer have smartphones registered to a plan. While Wi-Fi hotspots are commonplace in city centres and plans to roll out $3 \mathrm{G}$ coverage were announced by telecommunications provider ETECSA at the end of 2018 (ETECSA 2018), Wi-Fi cards and data plans are prohibitively expensive, especially for those without peso convertible salaries. Many Cubans who own phones are only able to do so through remittances or gifts from friends or family abroad. As a result, the digital tourist gaze of Havana completely dominates any representations of the city by its own residents, in ways that are particular to the Cuban context: a broad cross-section of Instagram contributors post images of London, for instance. In short, accounts by residents are far outnumbered by those run by Cuban tourism bodies MINTUR and Havanatur and the sum of personal tourist accounts such as those considered in this research. While the emergence of a new generation of Cuban 'digital millennials' and Instagram influencers will be transformative in this regard, the possibility of representing the self and the city through Instagram remains grossly asymmetrical and continues to privilege the tourist gaze.

Lastly, it is significant that part of the valued status Cuba holds as a nostalgic destination rests on the relative absence of device screens and internet connectivity. The island's current trendiness lies, in some measure, in the possibility of disconnecting, based on the notion that constant connectivity is a burden that ought to be escaped while on holiday. Cuba has therefore gained the positive reputation as a site of 'digital detox', despite the fact that the strategic development of the tourism industry since the 1990s has been inseparable from the use of digital technologies and the internet (Venegas 2010). Travel magazine Wanderlust includes Cuba in a list of top ten 'digital detox' destinations, selected on the basis of the tourist's quest to embrace 'powering down and tuning in to the world right before your eyes' (Higgins 2018). Travel bloggers such as Dannielle Lily also endorse the embodied 'presentness' that the digital detox imposes: 'Most of us spend a huge portion of our days immersed in the online world, and it felt good [in Cuba] to unplug and remind myself about the flesh and bones of my life' (Lily 2015). Instagram captions similarly referred to the pleasure, self-awareness and self-improvement to be found in disconnecting from digital technology while in Cuba: one user writes, 'Cuba's virtually non-existent Wi-Fi gave me a much needed break to recharge, live in the moment and take in the beautiful sites the island has to offer... Being disconnected for an extended period of time was refreshing beyond belief' (Eat Shop Travel, 2018). Appreciation for this aspect of Cuban reality, framed through markedly nostalgic terms, is nevertheless expressed through an exclusively online mode. Tourists' nostalgia for an authenticity that predates digital technology is facilitated by the use of digital technology; it represents a longing for something that is complicated through the very fact of its medium.

With these asymmetries in mind, the representational power of Instagram photography should not be taken for granted. We may think of this asymmetry as digital imperialism, in that tourist photographers (re)produce the traditional, predigital Other online and revere difference whilst almost exclusively operating and determining the means of representation through which those narratives and visions are articulated. Terms such as 'digital colonialism' have been used to describe the aggressive expansion into developing countries by tech transnationals: Facebook, for instance, has attracted criticism for marketing 'free' services that disregard local linguistic and cultural suitability in favour of Western corporate content while covertly harvesting huge amounts of user data (Global Voices 2017). Little of the product value of smartphones and tablets is captured by the economies of the developing countries in which they are produced (Timmer et al. 2014); the millions of dollars Instagram generates are concentrated in Silicon Valley. Smartphones that feature apps such as (Facebook-owned) Instagram are consequently heavy with political and cultural significance as they travel across borders and are used by tourists to frame and capture local subjects and themselves.

\section{$\underline{\text { Conclusion }}$}

Despite the paucity of studies of Instagram, this paper has proposed that the platform plays a significant role in circulating images that reflect and stimulate tourism to Cuba during a time of heightened visibility. While the motifs mentioned here - crumbling architecture, faded revolutionary slogans, cracked paint in ice-cream hues, aestheticized scarcity in the everyday, intimate portraiture, and tourist self-portraiture - correspond with and extend the nostalgic post-Soviet 
exotic conceptualized by Whitfield (2008), Dopico (2002) and Kent (2011), Instagram filters and effects may further intensify this aesthetic by 'ageing' the photo and drawing out colours and textures. Tourism photography on Instagram is not simply a way of documenting travel to Havana but also a primary mode of imagining and experiencing the city. It draws on Havana's historic symbolic potency and perpetuates it in new ways, allowing networked images to be shared with a vast audience online. The repetition of certain tropes, scenes and sites in tourists' photos on the platform reinforces their symbolic value as worthy of the gaze, informing and constructing that gaze. The combination of specific images with suggestive captions hints at reflections based on recent political and economic turbulence, including the nostalgia provoked by tourism itself, but these reflections are rarely articulated in full. The technology of Instagram thus facilitates and significantly expands an experience of gazing on Havana which obscures Cuba's historical place in the long yet asymmetrical development of globalization (Sheller 2003: 1) as well as bearing the traces of nostalgia for a pre-digital world - a nostalgia that is even more complex and contradictory given the format.

The consequences of the vast volume of images of Havana online, and on Instagram in particular, merit serious consideration. Instagram photography reinforces Havana's longstanding conflation with the photographic image, especially as metadata organizes these representations under the anchoring meaning-relay of hashtags, geotags and captions. The networked image becomes drawn into curated sequences through the activation of this searched metadata by the user. Snapshots become visible to global others, suggesting that, as the scopic mode is not simply engaged to record travel but rather motivates the tourist experience, the mobile Instagram photo image may encourage others to travel (i.e., become 'mobile'). This premise, following Gries (2013) and MacDowall and de Souza (2018) has methodological potential for future studies of images circulated online. The tourist gaze is expanded here to include new networked dimensions. However, in the context of Cuba, a lack of access to digital technologies to date has resulted in a strongly asymmetric gaze from the outside in.

\section{Works cited}

Barthes, Roland, 1981. Camera Lucida: Reflections on Photography (New York: Hill \& Wang).

Behar, Ruth, 2002. 'While Waiting for the Ferry to Cuba: Afterthoughts about Adio Kerida', Michigan Quarterly Review 41.4: 651-77.

Berg, Mette Louise, 2004. 'Tourism and the Revolutionary New Man: The Specter of Jineterismo in Late Special Period Cuba', Focaal 43: 46-56.

Bobes, Velia Cecilia, 2011. 'Visits to a Non-Place: Havana and Its Representation(s)', in Havana

Beyond the Ruins: Cultural Mappings since 1989, ed. Anke Birkenmaier and Esther Whitfield

(Durham, NC: Duke University Press), pp. 15-30.

Boyd, Danah, and Kate Crawford, 2012. 'Critical Questions for Big Data', Information, Communication and Society 15.5: 662-79.

Cabrera, Diana Rita, 2017. 'Seven Selfie-Worthy Places in Havana', Lonely Planet. www.lonelyplanet.

com/cuba/havana/travel-tips-and-articles/seven-selfie-worthy-places-in-havana/40625c8c8a11-5710-a052-1479d2769c7f. Accessed 12 March 2020.

'Cuba Espera Superar La Cifra de 5 Millones de Turistas En 2019, Reveló Ministro Del Sector', 2019. Granma.cu. www.granma.cu/cuba/2019-03-04/cuba-espera-superar-la-cifra-de-5-millonesde-turistas-en-2019-revelo-ministrodel-sector-04-03-2019-09-03-03. Accessed 4 November 2020.

Dillon, Brian, 2014. Ruin Lust (London: Tate Gallery Publishing).

Dinhopl, Anja, and Ulrike Gretzel, 2016. 'Selfie-Taking as Touristic Looking', Annals Of Tourism Research 57 (March): 126-39.

Dopico, Ana Maria, 2002. 'Picturing Havana: History, Vision, and the Scramble for Cuba', Nepantla: Views from the South 3.3: 451-93.

Eat Shop Travel [@eat.shop.travel], 2018. 'I’M BACK!!!! Currently in Mexico after an adventure filled trip to Cuba'. Instagram, 2 March 2018. https://www.instagram.com/p/Bf1IwzDFAgw/. Accessed 10 December 2020. Edwards, E., 1996. 'Postcards: Greetings from Another World', in The Tourist Image: Myths and Myth Making in Tourism, ed. Tom Selwyn (Chichester, UK: John Wiley and Sons), pp.197-222. 
ETECSA, 2018. 'Se Amplía Servicio Internet En Cuba Con El Acceso a Través de La Red Móvil (3G) 4 de Diciembre de 2018' (Havana: Empresa de Telecomunicaciones de Cuba). www.etecsa.cu/

inicio/se_amplia_servicio_internet_en_cuba. Accessed 4 November 2020.

Fehimović, Dunja, 2018. 'The Paradoxes of the "Cuban Brand": Authenticity, Resistance, and Heroic Victimhood in Cuban Film', in Branding Latin America: Strategies, Aims, Resistance, ed. Dunja Fehimović and Rebecca Ogden (Lanham, MD: Lexington), pp. 175-98.

Firmat, Gustavo Pérez, 2010. The Havana Habit (New Haven, CT: Yale University Press).

Gasiorowski, Dominika, 2019. 'Photographing Children in Mexico City's Red-Light Districts', Bulletin of Latin American Research 38.1: 66-81.

Global Voices, 2017. Free Basics in Real Life. Six Case Studies on Facebook's Internet 'on Ramp' Initiative from Africa, Asia and Latin America (Amsterdam: Stichting Global Voices). Advox.globalvoices.

org/wpcontent/uploads/2017/08/FreeBasicsinRealLife_FINALJuly27.pdf. advox.globalvoices.org/wpcontent/uploads/2017/08/FreeBasicsinRealLife_FINALJuly27.pdf. Accessed 3 November 2020.

Gries, Laurie E., 2013. 'Iconographic Tracking: A Digital Research Method for Visual Rhetoric and Circulation Studies', Computers and Composition 30.4: 332-48.

Hernandez-Reguant, A., 2009. Cuba in the Special Period: Culture and Ideology in the 1990s (Basingstoke, UK: Palgrave Macmillan).

Higgins, Emma, 2018. '10 Breathtakingly Beautiful Places That Are Perfect for a Digital Detox',

Wanderlust, 9 January. www.wanderlust.co.uk/content/10-breathtakingly-beautiful-placesfor-digital-detox/. Accessed 20 November 2020.

Highfield, Tim, and Tama Leaver, 2015. 'A Methodology for Mapping Instagram Hashtags', First Monday 20.1: 1-11. Hochman, Nadav, 2014. 'The Social Media Image', Big Data \& Society 1.2: 1-15.

Hollinshead, Keith, 1999. 'Surveillance of the Worlds of Tourism: Foucault and the Eye-of-Power', Tourism Management 20.1: 7-23.

Honig, Christopher D. F., and Lachlan MacDowall, 2017. 'Spatio-Temporal Mapping of Street Art Using Instagram', First Monday 22.3. doi.org/10.5210/fm.v22i3.7072.

Jenkins, Olivia, 2003. 'Photography and Travel Brochures: The Circle of Representation', Tourism Geographies: An International Journal of Tourism Place, Space and the Environment 5.3: 305-28.

Kent, James C., 2011. 'Constructing the City: Spatializing the Real and Imagined Havana in Visual Culture, 1933-2010', Doctoral thesis, Royal Holloway, University of London. ethos.bl.uk/OrderDetails.do?uin=uk.bl.ethos.586913. Accessed 4 November 2020.

_, 2017. '(Un)staging the City: Havana and the Music Film (2001-2005)', Hispanic Research Journal 18.1: 74-91.

-, 2019. Aesthetics and the Revolutionary City: Real and Imagined Havana (Basingstoke, UK: Palgrave Macmillan).

Larsen, Jonas, John Urry and Kay W. Axhausen, 2007. 'Networks and Tourism', Annals Of Tourism Research 34.1: 24462.

Leaver, Tama, and Tim Highfield, 2018. 'Visualising the Ends of Identity: Pre-Birth and Post-Death on Instagram', Information, Communication and Society 21.1: 30-45.

Levi, V. G., and S. Heller, 2002. Cuba Style: Graphics from the Golden Age of Design (New York: Princeton Architectural Press).

Lily, Dannielle, 2015. 'Surviving Without Wi-Fi Abroad: My Digital Detox In Cuba', While I'm Young, 16 October. www.whileimyoung.com/surviving-without-wifi-abroad/. Accessed 25 June 2018.

Lyons, Siobhan, 2018. Ruin Porn and the Obsession with Decay (Basingstoke, UK: Palgrave Macmillan).

MacCannell, Dean, 1973. 'Staged Authenticity: Arrangements of Social Space in Tourist Settings', The American Journal of Sociology 79.3: 589-603.

—, 1999. The Tourist: A New Theory of the Leisure Class (Berkeley: The University of California Press).

MacDowall, Lachlan John, and Poppy de Souza, 2017. “I'd Double Tap That!”: Street Art, Graffiti, and Instagram Research', Media Culture \& Society 40.1: 3-22. 
Mostafanezhad, Mary, and Roger Norum, 2018. 'Tourism in the Post-Selfie Era', Annals of Tourism Research 70: 13132. doi.org/10.1016/j.annals.2017.11.008.

Ogden, Rebecca, 2019. 'Lonely Planet: Affect and Authenticity in Guidebooks of Cuba', Social Identities 25.2: 156-68. ONEI, 2019. 'Anuario Estadístico de Cuba, 2018. Capítulo 17: Tecnología de La Información y Las Comunicaciones',

Oficina Nacional de Estadistica e Información. www.onei.gob.cu/node/14211. Accessed 4 November 2020.

Pratt, Mary Louise, 2008. Imperial Eyes: Travel Writing and Transculturation (London: Routledge).

Quiroga, Jose, 2005. Cuban Palimpsests (Minneapolis: University of Minnesota Press).

Real, Patricio, and Joseph Scarpaci, 2011. 'Barbacoas: Havana's New Inward Frontier', in Havana Beyond the Ruins: Cultural Mappings After 1989, ed. Anke Birkenmaier and Esther Whitfield (Durham, NC: Duke University Press), pp. 53-72.

Rubinstein, Daniel, and Katrina Sluis, 2008. 'A Life More Photographic: Mapping the Networked Image', Photographies 1.1: 9-28.

_, 2013. 'Concerning the undecidability of the digital image', Photographies, 6.1: 151-58, doi.org/1 $0.1080 / 17540763.2013 .788848$.

Scarles, Caroline, 2013. 'The Ethics of Tourist Photography: Tourists' Experiences of Photographing Locals in Peru', Environment and Planning Development, Society \& Space 31.5: 897-917.

Schwartz, Rosalie, 1999. Pleasure Island: Tourism and Temptation in Cuba (Lincoln: University of Nebraska Press). Sheller, Mimi, 2003. Consuming the Caribbean: From Arawaks to Zombies (New York: Routledge).

Sontag, Susan, 1977. On Photography (London: Macmillan).

Thompson, Krista A., 2006. An Eye for the Tropics: Tourism, Photography and Framing the Caribbean (Durham, NC: Duke University Press).

Thornton, Niamh, 2010. 'YouTube: Transnational Fandom and Mexican Divas', Transnational Cinemas 1.1: 53-67.

Tiidenberg, K., and N. K. Baym, 2017. 'Learn It, Buy It, Work It: Intensive Pregnancy on Instagram', Social Media and Society 3.1: 1-13. doi.org/10.1177/2056305116685108.

Timmer, Marcel P., Abdul Azeez Erumban, Bart Los, Robert Stehrer, and Gaaitzen J. de Vrie, 2014. 'Slicing Up Global Value Chains', The Journal of Economic Perspectives: A Journal of the American Economic Association. 28.2: 99-118.

Urry, John, 1990. The Tourist Gaze (London: Sage).

Venegas, Cristina, 2010. Digital Dilemmas: The State, the Individual, and Digital Media in Cuba (New Brunswick, N.J: Rutgers University Press).

Webb, Jennifer B., Erin Vinoski Thomas, Courtney B. Rogers, Victoria N. Clark and Elizabeth N. Hartsell, 2019. 'Fitspo at Every Size? A Comparative Content Analysis of \#curvyfit versus \#curvyyoga Instagram Images', Fat Studies 8.2: $154-72$.

Whitfield, Esther, 2008. Cuban Currency: The Dollar and 'Special Period' Fiction (Minneapolis: University of Minnesota Press). 